\title{
Function is more reliable than quantity to follow up the humoral response to the Receptor Binding Domain of SARS- CoV-2 Spike protein after natural infection or COVID-19 vaccination.
}

Carlos A. Sariol, ${ }^{\mathrm{a}, \mathrm{b}, \mathrm{c}^{\star}}$, Petraleigh Pantoja ${ }^{\dagger}$, Crisanta Serrano-Collazo ${ }^{\mathrm{b}}$, Tiffany Rosa-Arocho ${ }^{\mathrm{b}}$, Albersy Armina ${ }^{a}$, Lorna Cruz ${ }^{a, b}$, E. Taylor Stone ${ }^{d}$, Teresa Arana ${ }^{a, b}$, Consuelo Climent ${ }^{e}$, Gerardo Latonif, Dianne Atehortua ${ }^{g}$, Christina Pabon-Carrero ${ }^{g}$, Amelia K. Pinto ${ }^{d}$, James D. Brien ${ }^{d}$ and Ana M. Espino ${ }^{a^{*} \dagger}$

${ }^{a}$ Department of Microbiology and Medical Zoology, University of Puerto Rico-Medical Sciences Campus, San Juan, PR, USA, 'Unit of Comparative Medicine, University of Puerto Rico-Medical Sciences Campus, San Juan, PR, USA, ${ }^{\mathrm{c}}$ Department of Internal medicine, University of Puerto Rico-Medical Sciences Campus, San Juan, PR, USA, ${ }^{d}$ Department of Molecular Microbiology and Immunology, Saint Louis University, St Louis, Missouri, USA. ${ }^{\mathrm{e} B l o o d ~ B a n k ~ M e d i c a l ~ C e n t e r, ~}$ Medical Center, San Juan, PR, USA, 'Banco de Sangre de Servicios Mutuos, Guaynabo, PR, USA, Puerto Rico Science, Technology and Research Trust, PR, USA.

${ }^{\dagger}$ These authors have contributed equally to this work and share first authorship.

*Address correspondence to Carlos A. Sariol carlos.sariol1@upr.edu or Ana M Espino, ana.espino1@upr.edu

Keywords: SARS-CoV-2, COVID-19 Vaccine, Neutralization, Serology, Protection 
medRxiv preprint doi: https://doi.org/10.1101/2021.06.02.21257975; this version posted August 10, 2021. The copyright holder for this preprint (which was not certified by peer review) is the author/funder, who has granted medRxiv a license to display the preprint in perpetuity.

It is made available under a CC-BY-NC-ND 4.0 International license .

\section{Abstract}

Both the SARS-CoV-2 pandemic and emergence of variants of concern have highlighted the need for functional antibody assays to monitor the humoral response over time. Antibodies directed against the spike (S) protein of SARS-CoV-2 are an important component of the neutralizing antibody response. In this work, we report that in a subset of patients-despite a decline in total S-specific antibodies-neutralizing antibody titers remain at a similar level for an average of 98 days in longitudinal sampling of a cohort of 59 Hispanic/Latino patients exposed to SARS-CoV-2. We also report that serum neutralization capacity correlates with lgG titers, wherein $\lg$ I 1 was the predominant isotype (62.71\%), followed by $\lg$ G4 (15.25\%), IgG3 (13.56\%), and $\lg \mathrm{lg} 2(8.47 \%)$ at the earliest tested timepoint. IgA titers were detectable in just $28.81 \%$ of subjects, and only $62.71 \%$ of subjects had detectable lgM in the first sample despite confirmation of infection by a molecular diagnostic assay. Our data suggests that $100 \%$ of seroconverting patients make detectable neutralizing antibody responses which can be quantified by a surrogate viral neutralization test. Examination of sera from 10 out of the 59 subjects which had received an initial first dose of mRNA-based vaccination revealed that both IgG titers and neutralizing activity of sera were higher after vaccination compared to a cohort of 21 SARS-CoV-2 naïve subjects. One dose was sufficient for induction of neutralizing antibody, but two doses were necessary to reach $100 \%$ surrogate virus neutralization in subjects irrespective of previous SARS-CoV-2 natural infection status. Like the pattern seen after natural infection, after the second vaccine dose, the total anti-S antibodies titers declined, however, neutralizing activity remained relatively constant for more than 80 days after the first vaccine dose. The decline in anti-S antibody titer, however, was significantly less in pre-exposed individuals, highlighting the potential for natural infection to prime a more robust immune response to the vaccine. Furthermore, our data indicates that-compared with mRNA vaccination-natural infection induces a more robust humoral immune response in unexposed subjects. However, this difference was significant only when neutralizing antibody titers were compared among the two groups. No differences were observed between naturally infected and vaccinated individuals when total anti-S antibodies and IgG titers were measured. This work is an important contribution to understanding the natural immune response to the novel coronavirus in a population severely impacted by SARS-CoV-2. Furthermore, by comparing the dynamics of the immune response after the natural infection vs. the vaccination, these findings suggest that a functional neutralizing antibody tests are more relevant indicators than the presence or absence of binding antibodies. In this context, our results also support standardizing methods of assessing the humoral response to SARS-CoV-2 when determining vaccine efficacy and describing the immune correlates of protection for SARS-CoV-2. 
medRxiv preprint doi: https://doi.org/10.1101/2021.06.02.21257975; this version posted August 10, 2021. The copyright holder for this preprint (which was not certified by peer review) is the author/funder, who has granted medRxiv a license to display the preprint in perpetuity.

It is made available under a CC-BY-NC-ND 4.0 International license .

\section{Introduction}

The COVID-19 pandemic presents an unprecedented challenge to the scientific community. At the same time, it is adding advancing our collective knowledge in molecular biology, epidemiology, and immunology at an accelerated speed. One of the crucial questions still under scrutiny is the magnitude and durability of the immune response to natural infection with SARS-CoV-2, especially given the fact that virus-specific antibody (ab) responses are relatively short-lived following SARS-CoV and common cold coronavirus infections (CCC) (Sette and Crotty 2020). Further complicating this scenario is the recent availability of new vaccine formulations, which are accessible to both previously infected and immunologically naïve individuals. The kinetics of the humoral response in vaccinees, both with and without prior SARS-CoV-2 exposure, is an area of active research with many outstanding questions.

To begin to address these questions, we followed a cohort of 59 individuals (volunteers or convalescent plasma donors) at different time points following natural infection with SARS-CoV-2. In addition, we chose a set of 7 of those individuals plus 3 additional subjects $(n=10)$ which we then compared with 21 uninfected-vaccinated subjects $(n=21)$. Serum samples for both vaccinated groups were collected between 12 and 28 days after each of the two doses of mRNA vaccine and a third sample was collected between 19 and 83 days after the second dose. Because the limited period of SARS-CoV-2 circulation, studies on the quantity, quality and extent of long-term memory responses are still underway. Recent works on the durability of the humoral immune response after the natural infection with SARS-CoV-2 showed the presence of neutralizing antibodies for several months (Dan et al. 2021, Figueiredo-Campos et al. 2020, L'Huillier et al. 2021, Lau et al. 2021, Wajnberg et al. 2020) or the persistence of IgG responses over the first few months after infection, which is strongly correlated with neutralizing antibody titer (lyer et al. 2020, L'Huillier, Meyer, Andrey, Arm-Vernez, Baggio, Didierlaurent, Eberhardt, Eckerle, Grasset-Salomon, Huttner, Posfay-Barbe, Royo, Pralong, Vuilleumier, Yerly, Siegrist and Kaiser 2021). Since the onset of the COVID-19 pandemic, functional neutralization assays using serum antibodies has been severely limited due to the requirement for a biosafety level 3 (BSL-3) facility to grow SARS-CoV-2. However, in a relatively short period of time, several surrogate neutralization assays have become available with an excellent performance profile when compared to the classical focus reduction neutralization test (FRNT) (Jeewandara et al. 2021, L'Huillier, Meyer, Andrey, Arm-Vernez, Baggio, Didierlaurent, Eberhardt, Eckerle, GrassetSalomon, Huttner, Posfay-Barbe, Royo, Pralong, Vuilleumier, Yerly, Siegrist and Kaiser 2021, Salazar et al. 2020, Schmidt et al. 2020, Tan et al. 2020, Taylor et al. 2021). For these studies, we choose the cPass SARS-CoV-2 Surrogate Virus Neutralization Test Kit (GenScript, USA) 
medRxiv preprint doi: https://doi.org/10.1101/2021.06.02.21257975; this version posted August 10, 2021. The copyright holder for this preprint (which was not certified by peer review) is the author/funder, who has granted medRxiv a license to display the preprint in perpetuity.

It is made available under a CC-BY-NC-ND 4.0 International license .

which measures the interaction of purified SARS CoV-2 spike protein receptor binding domain (RBD) with the extracellular domain of the human ACE2 receptor (Taylor, Hurst, Charlton, Bailey,

72 Kanji, McCarthy, Morrison, Huey, Annen, DomBourian and Knight 2021). In our hands, this

73 assay showed the best sensitivity and the lower false negative rate compared to five other

74 assays (Tan, Saw, Chew, Huak, Khoo, Pajarillaga, Wang, Tambyah, Ong, Jureen and Sethi

75 2020). Furthermore, this assay was granted an Emergency Use Authorization (EUA) by the

76 Federal Drug Administration (FDA) for the detection of SARS-CoV-2 neutralizing antibodies.

77 Interestingly, we detected a small number of cases $(n=6)$ where neutralization activity was still

78 present, although S-specific lgG titers were undetectable by our method (OD <.312).

Recently, debate has centered around the efficacy of the natural immune response to SARS-CoV-2 vs. mRNA vaccines. Our work which examines patients in a predominantly Latino population-confirms that following a natural infection neutralizing antibody titers remained detectable at high levels for 4 to 7 months. We also demonstrate that the quantity and the quality of the antibody response induced by the natural infection is significantly higher in titer of both binding and neutralizing antibodies when compared to the response induced by mRNA vaccination. There is limited information regarding the magnitude of the immune response to vaccines against SARS-CoV-2 in naive vs. pre-exposed subjects with clinical trial reports being limited in scope when addressing this issue (Baden et al. 2021, Sahin et al. 2020, Voysey et al. 2021, Walsh et al. 2020). Nevertheless, consistent with our findings presented here, a few reports suggest that antibody titers in previously infected persons trend or are significantly higher than in SARS-CoV-2 naïve persons (Bradley et al. 2021, Khoury et al. 2021, Krammer et al.

91 2021, Prendecki et al. 2021). ,Together the results suggest that a single dose may be sufficient 92 during the early stages of vaccine rollout in order to optimize vaccine availability worldwide. 
medRxiv preprint doi: https://doi.org/10.1101/2021.06.02.21257975; this version posted August 10, 2021. The copyright holder for this preprint (which was not certified by peer review) is the author/funder, who has granted medRxiv a license to display the preprint in perpetuity.

It is made available under a CC-BY-NC-ND 4.0 International license .

\section{Material and Methods}

\section{Cohorts}

The samples in this study were derived from two main sources: 1-From adult volunteers ( $>21$ years old) participating in the IRB approved clinical protocol "Molecular Basis and Epidemiology of Viral infections circulating in Puerto Rico", Pro0004333. Protocol was submitted to, and ethical approval was given by, Advarra IRB on April 21, 2020. This is a running 5 year protocol which encompasses the collection of blood samples from adults exposed or suspected to be exposed to viral infections. An Informed Consent Form and a study questionnaire also approved by the IRB were administered to the volunteers. From March 2020 to April 2021, we were able to follow up for serial samples with at least 59 subjects. From those 59, five (5) subjects received two doses of Pfizer's vaccine and two received Moderna's formulation. We also added three vaccinated subjects for a total of 10 (ID511, ID512 and ID297). From those three, two received Pfizer's and one Moderna's vaccine. All three subjects also consented to this study. In addition, a cohort of 21 vaccinated volunteers that were never exposed to SARS-CoV-2 were followed for 6 to eight months (Supplementary tables 1-3). Of these 21 vaccinated volunteers, eighteen (18) received Pfizer's vaccine and three (3) received Moderna's formulation. Those 21 subjects are part of the 59 subjects followed for months. During the follow-up period before vaccination, they never had symptoms or a positive serologic result. 2- De-identified blood samples received from local laboratories network and blood banks. These subjects were self-enrolled for the purpose of donating plasma for the treatment of COVID-19 patients. Subjects were verbally informed regarding the relevance of their participation in COVID19 research, and were informed of the possibility that their deidentified samples may be used for research purposes. Subjects were given the opportunity to ask questions of blood bank workers regarding their participation. Furthermore, collected samples were handled using the standard blood donors' protocols, and were accompanied by the blood bank's signed consent form, which also detailed the possibility that samples would be used for research purposes. In addition, prior to receipt, samples were stripped of all identifiers so that the information cannot be traced back to the individual.

As expected, some of the exposed subjects had more symptoms than others, with fever and loss of smell and taste being the most common symptoms. However, in this cohort, subjects did not need hospitalization or additional medical support in an emergency room setting.

\section{Detection of SARS-CoV-2 IgM antibodies}


medRxiv preprint doi: https://doi.org/10.1101/2021.06.02.21257975; this version posted August 10, 2021. The copyright holder for this preprint (which was not certified by peer review) is the author/funder, who has granted medRxiv a license to display the preprint in perpetuity.

It is made available under a CC-BY-NC-ND 4.0 International license .

CovlgM-Assay is an indirect ELISA for the determination of human $\lg M$ antibody class, which was optimized via checkerboard titration. This assay is a Laboratory Developed Test (LDT) with an Emergency Use Authorization (EUA) submitted to the U.S. Federal Drug Administration (FDA) (EUA202043). In summary, microplates were coated overnight at $4^{\circ} \mathrm{C}$ with

$1322 \mu \mathrm{g} / \mathrm{mL}$ of recombinant SARS-CoV-2 S1-RBD protein (GenScript No. Z03483-1) in carbonate-

133 bicarbonate buffer. Plates were washed 3 times with phosphate buffered saline (PBS) containing $1340.05 \%$ Tween-20 (PBST) and blocked for $30 \mathrm{~min}$ at $37^{\circ} \mathrm{C}$ with $250 \mu \mathrm{L} /$ well of $3 \%$ Bovine Serum 135 Albumin (BSA) in PBST. Diluted serum or plasma samples (1:100 in blocking buffer) were added 136 in duplicates to the wells and incubated at $37^{\circ} \mathrm{C}$ for $30 \mathrm{~min}$. The excess antibody was washed off 137 with PBST. Horseradish peroxidase (HRP) labeled-mouse anti-human IgM-mu chain (Abcam)

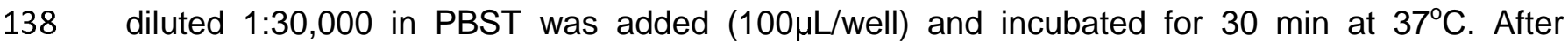

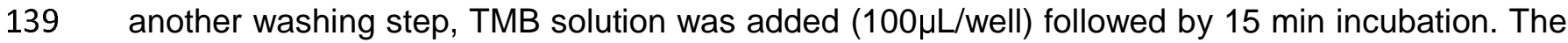
140 reaction was stopped by the addition of $50 \mu \mathrm{L} /$ well $10 \% \mathrm{HCl}$ and the absorbance was measured 141 at 450nm (A450) using a Multiskan FC reader (Thermo Fisher Scientific). In every CovlgM-Assay 142 determination, four wells in which samples were replaced by $100 \mu \mathrm{L} /$ well of PBST were included 143 as background control. Moreover, two in-house controls, a high positive control (HPC) and 144 negative control (NC) were included. HPC and NC were prepared by diluting an IgM anti-SARS145 CoV-2 at a concentration of $80 \mu \mathrm{g} / \mathrm{mL}$ and $0.070 \mu \mathrm{g} / \mathrm{mL}$, respectively, in PBST containing $10 \%$ 146 glycerol. The IgM anti-SARS-CoV-2 was purified from the plasma of a convalescent patient using $1475 / 5$ HiTrap IgM columns (GE Healthcare, USA). When the OD value of a serum or plasma 148 sample at the working dilution (1:100) was equal or less than the cut-point (OD450=0.229), the 149 CovlgM-Assay in the sample was assumed to be negative.

\section{Detection of SARS-CoV-2 IgG antibodies}

152 IgG antibodies were detected and quantified using the CovlgG-Assay (Espino et al. 153 2020). This assay is a Laboratory Developed Test (LDT) with an Emergency Use Authorization 154 (EUA) submitted to the U.S. Federal Drug Administration (FDA) (EUA201115). It is an indirect 155 ELISA for quantitative determination of human $\lg G$ antibody class, which was optimized by 156 checkerboard titration. In summary, disposable high bind flat-bottomed polystyrene 96-wells 157 microtiter plates (Costar, Corning MA No. 3361) were coated overnight at $4^{\circ} \mathrm{C}$ with $2 \mu \mathrm{g} / \mathrm{ml}$ of 158 recombinant SARS-CoV-2 S1-RBD/S2 protein (GenScript No. Z03483-1) in carbonate159 bicarbonate buffer (Sigma Aldrich No. 08058). Plates were washed 3 times with (PBST) and 160 blocked for $30 \mathrm{~min}$ at $37^{\circ} \mathrm{C}$ with $250 \mu \mathrm{l} /$ well of $3 \%$ non-fat, skim milk in PBST. Samples (serum or 161 plasma) were diluted 1:100 in PBST; 100 $\mathrm{L} /$ well was added in duplicates and incubated at $37^{\circ} \mathrm{C}$ 
medRxiv preprint doi: https://doi.org/10.1101/2021.06.02.21257975; this version posted August 10, 2021. The copyright holder for this preprint (which was not certified by peer review) is the author/funder, who has granted medRxiv a license to display the preprint in perpetuity.

It is made available under a CC-BY-NC-ND 4.0 International license.

162 for $30 \mathrm{~min}$. The excess antibody was washed off with PBST. Horseradish peroxidase (HRP) 163 labeled-mouse anti-human IgG-Fc specific (GenScript No. A01854) diluted 1:10,000 in PBST 164 was added $(100 \mu \mathrm{l} /$ well $)$ and incubated for $30 \mathrm{~min}$ at $37^{\circ} \mathrm{C}$. After another washing step, a

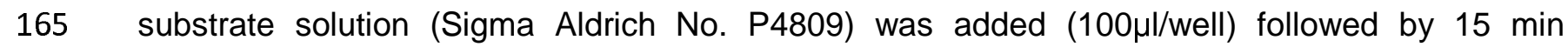
166 incubation. The reaction was stopped with $50 \mu \mathrm{l} /$ well $10 \% \mathrm{HCl}$ and the absorbance was measured 167 at $492 \mathrm{~nm}\left(\mathrm{~A}_{492}\right)$ using a Multiskan FC reader (Thermo Fisher Scientific). In every CovlgG-Assay 168 determination two in-house controls, a high positive control (HPC) and negative control (NC) 169 were included. HPC and NC were prepared by diluting an IgG anti-SARS-CoV-2 at a 170 concentration of $30 \mu \mathrm{g} / \mathrm{ml}$ and $0.070 \mu \mathrm{g} / \mathrm{ml}$, respectively in PBST containing $10 \%$ glycerol. The lgG 171 anti-SARS-CoV-2 was purified from plasma of a convalescent patient using a 5/5 HiTrap 172 rProtein-A column (GE Healthcare, USA). When the OD value of a serum or plasma sample at 173 the working dilution (1:100) was equal or less than the cutoff-point (OD492=0.312), the CovlgG174 Assay in the sample was assumed to be negative. However only samples with OD above of 1750.499 were reported as having a titer within a range of $1: 100$ to $\geq 1: 12,800$.

176 For isotyping ELISAs, the conjugate was changed for the specific isotype as follows: anti-lgA 177 (alpha chain specific-HRP (Sigma), anti-lgG1, 2, 3 and 4 Fc-specific-HRP (Southern Biotech). All 178 conjugates were used in a 1:3,000 dilution.

\section{cPass SARS-CoV-2 neutralization antibody detection method}

To determine the neutralizing activity of antibodies we used a surrogate viral neutralization test (C-Pass GenScript sVNT, Piscataway NJ) (Tan, Saw, Chew, Huak, Khoo, 183 Pajarillaga, Wang, Tambyah, Ong, Jureen and Sethi 2020, Taylor, Hurst, Charlton, Bailey, Kanji, 184 McCarthy, Morrison, Huey, Annen, DomBourian and Knight 2021). Briefly, serum or plasma 185 samples were diluted according to manufacturer's instructions and incubated with soluble SARS186 CoV-2 receptor binding domain (RBD-HRP) antigen for 30 minutes, mimicking a neutralization 187 reaction. Following incubation, samples were added to a 96 well plate coated with human ACE-2 188 protein. RBD-HRP complexed with antibodies are removed in a wash step. The reaction is 189 developed with tetramethylbenzidine (TMB) followed by a stop solution allowing the visualization 190 of bound RBD-HRP to the ACE2. Since this is an inhibition assay, color intensity is inversely 191 proportional to the amount of neutralizing antibodies present in samples. Data is interpreted by 192 calculating the percent of inhibition of RBD-HRP binding. Samples with neutralization activity of $193 \geq 30 \%$ indicates the presence of SARS CoV-2 RBD-interacting antibodies capable of blocking the 194 RBD-ACE2 interaction thus inhibiting viral entry into host cells. While this assay measures the 
medRxiv preprint doi: https://doi.org/10.1101/2021.06.02.21257975; this version posted August 10, 2021. The copyright holder for this preprint (which was not certified by peer review) is the author/funder, who has granted medRxiv a license to display the preprint in perpetuity.

It is made available under a CC-BY-NC-ND 4.0 International license .

195 blocking activity of those antibodies, for consistency and clarity this activity is referred to 196 throughout the text as 'percentage of neutralization'.

\section{Statistical Methods}

199 Statistical analyses were performed using GraphPad Prism 7.0 software (GraphPad 200 Software, San Diego, CA, USA). The statistical significance between or within groups evaluated 201 at different time points was determined using two-way analysis of variance (ANOVA) (Tukey's, 202 Sidak's or Dunnett's multiple comparisons test) or unpaired t-test to compare the means. The $p$ 203 values are expressed in relational terms with the alpha values. The significance threshold for all 204 analyses was set at 0.05 ; $p$ values less than 0.01 are expressed as $P<0.01$, while $p$ values less 205 than 0.001 are expressed as $P<0.001$. Similarly, values less than 0.005 are expressed as $206 \mathrm{P}<0.005$. Cohen's Kappa agreement follow Landis and Koch scale. The values $(\mathrm{K})$ were 207 considered as follows: poor agreement, $\mathrm{K}<0.02)$; fair agreement, $\mathrm{K}=0.21$ to 0.4 ; moderate 208 agreement, $\mathrm{K}=0.41$ to 0.6 ; substantial agreement, $\mathrm{K}=0.61$ to 0.8 ; very good agreement, $\mathrm{K}=0.81$ to $209 \quad 1.0$. 
medRxiv preprint doi: https://doi.org/10.1101/2021.06.02.21257975; this version posted August 10, 2021. The copyright holder for this preprint (which was not certified by peer review) is the author/funder, who has granted medRxiv a license to display the preprint in perpetuity.

It is made available under a CC-BY-NC-ND 4.0 International license .

\section{Results}

\section{Sample collection}

212 Subjects were enrolled and samples were collected as participants became willing 213 and available. However, the time between serial samples was very similar for all subjects. The 214 average time between the time of the documented infection and the first samples $(n=59)$ was 21540.37 days (minimum 12 days, maximum 97 days and two extreme cases with 127 and 176 days 216 for a median of 38 days). Once the subjects entered in the cohort, the average time between the 217 first and the second samples $(n=59)$ was 67.86 days (minimum 7 days, maximum 111 days, 218 median 67.5 days). The average time between the second and the third samples $(n=12)$ was 21999.5 days (minimum 63 days, maximum 159 days, median 95 days) (Supplementary table S1).

220 From the two subgroups, exposed-vaccinated and unexposed-vaccinated, serum samples were 221 collected between 15 to 20 days after each dose. In addition, a third sample from all 21 222 unexposed and from 8 out of the 10 pre-exposed participants was collected between 19 and 83 days after the second dose (average of 40.1 and of 81.6 days for the unexposed and preexposed groups respectively) or an average of 60.3 and 100.5 days after the first vaccine dose for the unexposed and pre-exposed groups respectively (Supplementary table S2). Highly relevant for our findings is that the sample used as baseline in the pre-exposed before vaccination, was collected in average 142 days after the confirmed infection (minimum 67 days, maximum 310 days, median 126.4 days) (Supplementary table S3).

\section{SARS-CoV-2 specific IgG titers decline over time}

Overall, the $\lg$ titers in the cohort of 59 subjects were significantly higher (geometric mean 1072) in the first set of samples than the second set of samples (geometric mean 618) $(p<$ 0.0473 ) or the third set of samples (geometric mean 537) ( $p<0.0474)$. We observed no significant differences between titers measured in the second and third sets of samples ( $p<$ 0.3085) (Figure 1A). The results are reported as OD450 in supplementary figure 1A and agree with estimated titers (Supplementary table S4).

238 in IgG titers (Figure 1B) while 19 (32.2\%) showed an increase in the IgG titers from the first to 239 the second set of samples (Figure 1C). We found no relationship between the elapsed time from 240 initial diagnosis to first sample collection and the change (e.g. increase or decrease) in lgG titers 241 between sample collections (Supplementary figure 2). From these results, we concluded that the 242 differences in the lgG titers in those groups from the first to the second set of samples were not 243 attributable to the time between collection. We also found no relationship between the elapsed 
medRxiv preprint doi: https://doi.org/10.1101/2021.06.02.21257975; this version posted August 10, 2021. The copyright holder for this preprint (which was not certified by peer review) is the author/funder, who has granted medRxiv a license to display the preprint in perpetuity.

It is made available under a CC-BY-NC-ND 4.0 International license.

244 time between the first and second sample collection for both groups (Supplementary figure 2).

245 We identified three subjects (ID137, ID195, and ID367) showing a unique trend towards an

246 increase in IgG titers of 2.13-, 8.65-, and 52.1-fold, respectively, between the second and third

247 sampling collections. Particularly, volunteer ID195 exhibited an initial 8.65-fold decrease in IgG

248 titer between the first and second sample collection (50 days elapsed) followed by an increase in

249 IgG titer between the second and third sample collection (75 days elapsed).

\section{SARS-CoV-2 specific IgM titers decline over time}

Among the 59 subjects in our cohort, 37 (62.71\%) had detectable IgM titers in the

253 first set of samples, while 18 (30.50\%) had detectable IgM titers in the second set of samples

254 (Supplementary figure $1 \mathrm{H}$ ). In five subjects out of the 12 where a third sample was collected, IgM

255 titers were still detectable. In some cases, subjects developed an lgM response for first time (in

256 volunteer ID313 IgM was detected as early as 12 days after the presumptive diagnosis and

257 persisted up to 192 days, or roughly 6.4 months). Overall, IgM titers showed a consistent pattern

258 of decline in the second sample for most individuals (86.44\%). Only one subject (ID265) showed

259 no appreciable change in IgM titers between the first and second sample collection (68 days

260 elapsed). One subject (ID313) displayed no measurable lgM titer at the time of the first and

261 second sampling (106 days elapsed), but appeared positive for lgM titers in the third sample

262 (146 days elapsed). We also found that in the second set of samples, 3 subjects out of 59

263 (5.08\%) displayed detectable IgM titers which were absent detectable IgG titers. Subject ID312

264 showed detectable IgM titers, but borderline IgG titers results in the third sample collected 57

265 and 69 days after the first and second dose, respectively (86 and 98 days after the presumptive

266 diagnosis). Subject ID105 still had detectable IgM titers 192 days after the presumptive diagnosis

267 was made. The earliest time point with detectable IgM titers was 12 days after the presumptive

268 infection (ID166), followed by 13 days (ID180) and 14 days (ID179) after diagnosis. In general,

$269 \operatorname{lgM}$ was detected in 37 subjects $(77.97 \%$ ) in the first set of samples (43 days post presumptive

270 infection). In 18 subjects (57.63\%), IgM was detected in the first and second set of samples (104

271 days post presumptive infection). In 4 subjects (6.77\%) no $\lg \mathrm{M}$ was detected in any of the serial

272 samples collected.

\section{IgG titers-but not IgM or IgA titers-correlate with neutralizing activity.}

275 As described previously, the correlation between estimated IgG titers by the CovlgG-

276 Assay and the neutralization capacity as measured by the Focus Reduction Neutralization Test

277 (FRNT) is extremely strong (Espino, Pantoja and Sariol 2020). For this work, we performed same 
medRxiv preprint doi: https://doi.org/10.1101/2021.06.02.21257975; this version posted August 10, 2021. The copyright holder for this preprint (which was not certified by peer review) is the author/funder, who has granted medRxiv a license to display the preprint in perpetuity.

It is made available under a CC-BY-NC-ND 4.0 International license .

278 analysis examining the correlation between $\lg G$ titers and functional neutralization capacity, 279 obtained in these studies using the surrogate assay cPass SARS-CoV-2 neutralization antibody 280 detection method. By applying a Kappa analysis, we first aimed to determine if both techniques 281 agree when classifying positive and negative samples using $<100 \%$ and $>30 \%$ as cutoff for the 282 IgG titers and percentage of neutralization respectively. We found moderate agreement between 283 IgG titer and neutralization capacity, with a Cohen's Kappa value of 0.4304 (Supplementary figure $2843 \mathrm{~A})$. We then aimed to determine whether both techniques agree when classifying samples with 285 high $\operatorname{lgG}$ titers and high neutralizing antibody titer. Similarly, we found moderate agreement 286 between IgG titer and neutralization capacity, with a Cohen's Kappa value of 0.5402 287 (Supplementary figure 3B). We completed the same analysis for $\lg \mathrm{M}$ and $\lg \mathrm{A}$ titers to explore the 288 contribution of those antibody subclasses to total neutralization capacity. We found that both 289 techniques (IgM titer and cPass) have a fair agreement when classifying positive and negative 290 samples (Cohen's Kappa $=0.2391$ ), while the $\lg A$ titer and the neutralization assay showed only a 291 slight agreement (Cohen's Kappa = 0.0618) (Supplementary figure 3C-D).

\section{Neutralizing activity remains constant over time}

To determine the durability of the neutralizing antibody response, we examined the neutralization capacity in our longitudinally collected samples. Our results showed consistent neutralizing antibody titers over time, with no change in the neutralization potential from the first (geometric mean 68.08\%) to the second (geometric mean 63.89\%) sample. Similarly, we saw no appreciable decline in neutralization potential from the second (geometric mean 63.89\%) to the third (geometric mean 60.36\%) sample (Figure 1D and supplementary table S4). We did, however, identify two distinct trends in the kinetics of serum neutralization potential over time. Similar to our findings with total lgG titers, in the first collected sample we found a decrease in the neutralizing activity relative to the second sample in $61.01 \%$ (36 out of 59) of the subjects. Conversely, $38.98 \%$ of subjects (23 out of 59 ) showed a decrease in neutralization activity (Figures $1 \mathrm{E}$ and $\mathrm{F}$ ) during the same timeframe. While the percentage of subjects experiencing an increase or a decrease in neutralization capacity and lgG titers between samples was similar, the change in neutralization capacity was less pronounced and not significant compared with significant changes in the lgG titers (Figure 1B). From these findings, we concluded that the neutralizing capacity remains relatively constant during the time we followed this cohort.

Similarly, we compared the neutralization potential of sera from subjects in the second and the third samples for the few subjects $(n=3)$ for which we were able to obtain a third sample. We identified one subject (ID313) showing a different pattern, with a 3.34-fold (68\%) 
medRxiv preprint doi: https://doi.org/10.1101/2021.06.02.21257975; this version posted August 10, 2021. The copyright holder for this preprint (which was not certified by peer review) is the author/funder, who has granted medRxiv a license to display the preprint in perpetuity.

It is made available under a CC-BY-NC-ND 4.0 International license.

312 increase in neutralizing activity from the second to the third sample. Another two subjects

313 showed an increase in IgG titers, but displayed a very limited increase in neutralizing activity of

314 1.2-fold (ID135) and 0-fold (ID195). Despite the variability in IgG titers, neutralizing activity

315 remained over $50 \%$ in a majority (90\%) of all three samples. The distinctive serological and

316 neutralization pattern for subject ID313 appears to be strongly related to the clinical evolution

317 (Supplementary figure 3).

318 We also identified 11 subjects without detectable SARS-CoV-2 specific IgG titers which showed 319 some degree of neutralization ranging from $36 \%$ to $76 \%$. Six out of those 11 subjects had no 320 detectable total IgG. On the other hand, there were 3 subjects with detectable lgG titers capable 321 of binding SARS-CoV-2 S protein, but with very limited or absent neutralization capacity 322 (Supplementary table S4).

\section{Natural infection induces high quality antibodies than one vaccine dose.}

Next, we wanted to compare the magnitude of the humoral immune response to naturally acquired SARS-CoV-2 infection to the mRNA-based COVID-19 vaccinations in unexposed subjects. For this purpose, we choose samples from 25 participants out of the 59 with the first sample collected between 12 and 39 days after the confirmed infection with SARS-CoV2 (average 26.23 days) and from 21 unexposed participants that received two doses of the Pfizer-BioNTech vaccine. Samples for the unexposed subjects were collected an average of 17.1 and 14.1 days after the first and the second dose, respectively. As shown in Figure 2A, the mean

332 time elapsed between the first sample collection after infection was significantly higher than the 333 time elapsed between the first sample collected after the vaccination in the unexposed cohort $334 \quad(p<0.0001)$. Despite this delay, we found that the total anti-S antibodies and the total IgG titers 335 were comparable after the infection or the first vaccine dose in the unexposed participants 336 (Figures 2B and D). However, the quality of the antibodies measured by the surrogate 337 neutralization assay showed a neutralizing activity significantly higher in the naturally infected 338 group compared with the unexposed-vaccinated group $(p<0.0003)$. This indicated to us a better 339 quality of the antibodies induced by naturally acquired infection when compared to vaccine340 induced neutralizing antibody activity (Figure 2D). As showed in Figures 2B and 2C, two vaccine 341 doses in unexposed individuals were necessary to significantly increase the total antibody titers 342 and $\lg$ titers compared to individuals in the pre-exposed group $(p<0.0004)$. The magnitude of 343 neutralization was also significantly increased in pre-exposed individuals, but more modestly 344 than the quantity $(p<0.0294)$, suggesting that the increase in antibody quantity induced by the 
medRxiv preprint doi: https://doi.org/10.1101/2021.06.02.21257975; this version posted August 10, 2021. The copyright holder for this preprint (which was not certified by peer review) is the author/funder, who has granted medRxiv a license to display the preprint in perpetuity.

It is made available under a CC-BY-NC-ND 4.0 International license .

345 two vaccine doses was not accompanied by a similar increase in the quality of the neutralizing

346 antibody response (Figure 2D).

\section{Neutralization is sustained in naïve and pre-exposed-vaccinated subjects}

Samples were collected between 12 to 28 days after each dose with a mean of 19 days and of 14 days for the pre-exposed group and of 12 days and 26 days for the unexposed groups after the first and second dose respectively. An additional third sample from all 21 unexposed individuals and from 8 out of the 10 pre-exposed individuals was collected between 19 and 83 days after the second dose, respectively (Supplementary table S2). For the first sample collected following the first dose, there were no significant differences in the time elapsed between sample collections for the pre-exposed and unexposed subjects. However, there was a significant difference $(p<0.0001)$ in the time elapsed between sample collections following the second dose (third sample) between the pre-exposed and unexposed groups (Supplementary figure S4). The geometric mean baseline $\lg$ titers in the pre-exposed population was 726 (range: 125 to 7191 ) and increased to a geometric mean of 5239 (range: 3408 to 6586) after the first dose (Figure 3B and supplementary tables S5 and S6). After the second dose, the geometric mean decreased to 3980 (range: 2273 to 5847), and we observed no significant difference in lgG titers after the first dose. On the other hand, the 21 vaccinated, unexposed subjects were negative for S-specific IgG at baseline. After the first dose, the lgG titers significantly increased to a geometric mean of 832 (range: 196 to 9365, $\mathrm{p}<0.0001$ ) and after the second dose, those values significantly increased $(p<0.0001)$ to a geometric mean of 5446 (range: 3346 to 10,239 ) 366 (Figure 3B).

In the second sample, which was collected after the second dose (third sample) in the unexposed group, the geometric mean of the titers was 1518 (range: 409 to 3278). In the preexposed group, the geometric mean of the titers was 1323 (range: 568 to 3536). In both groups, we observed a a significant decrease from the lgG titers detected in the first samples relative to titers after the second dose $(p<0.0001$ and $p=0.0192$ for the unexposed and pre-exposed groups, respectively).

In our cohort, the total IgG values were consistent with reported IgG titers (Figure 3A). We looked first at the $\lg \mathrm{G} 1$ isotype, the main contributor to the total $\lg G$ in the cohort of 59

375 individuals. The first dose induced a significant increase in this isotype for both groups $(p<0.0018$ 376 and $p<0.0001$ for the unexposed and pre-exposed vaccinated groups, respectively). However, 377 the effect of the boost was significantly higher in the pre-exposed group $(p<0.0001)$ suggesting a 378 role for natural infection in this significant difference. Remarkably, the second dose appeared to 
medRxiv preprint doi: https://doi.org/10.1101/2021.06.02.21257975; this version posted August 10, 2021. The copyright holder for this preprint (which was not certified by peer review) is the author/funder, who has granted medRxiv a license to display the preprint in perpetuity.

It is made available under a CC-BY-NC-ND 4.0 International license.

379 provide a benefit in boosting lgG1 titers in the unexposed, vaccinated group only $(p<0.0001)$.

380 IgG1 values after the second dose in the unexposed, vaccinated group reached values

381 comparable to that of the pre-exposed vaccinated group after just one dose. We observed no

382 significant differences in the levels of IgG1 between groups following the second dose

383 (Supplementary Figu

384 re 5).

The geometric mean baseline of neutralization activity in the pre-exposed population was $69.46 \%$ (range: 39 to $97 \%$ ) and increased significantly $(p<0.0001)$ to a geometric mean of 97.99\% (range: 97 to 98\%) after the first dose (Figure 3C and Supplementary Table S5). However, following the second dose, the values remained similar in range, with a mean of $97.19 \%$. On the other hand, the 21 naïve-vaccinated persons were negative for neutralization at baseline (geometric mean: 15\%). After the first dose, neutralization significantly increased $(p<0.0001)$ to a geometric mean of $57.34 \%$ (range: $28 \%$ to $76 \%$, with one outlier of $96 \%$ ). The second dose produced an additional significant boost $(\mathrm{p}<0.0001)$ to a geometric mean of $96.85 \%$ (in a range from 95\% to 98\%) (Figure $3 \mathrm{C}$ ). Contrary to the trend we observed in total antibody titers and IgG titers (Figures $3 \mathrm{~A}$ and $\mathrm{B}$ ), the neutralizing activity was retained at very similar level in both groups in the third sample collected. The geometric mean for the unexposed group was $94.5 \%$ (in a range from $86 \%$ to $98 \%$ ), while the pre-exposed group had a geometric mean of $96.62 \%$ (in a range from $96 \%$ to $98 \%$ ). Though there was no significant difference in neutralization capacity between groups, nine (9) subjects in the unexposed group showed values lower than $5 \%$ neutralization. This resulted in a 1.02-fold decrease in the value of neutralization capacity in the unexposed group, while there were no changes in neutralization capacity the preexposed cohort.

Among the previously exposed subjects we examined, 5 out of 10 (50\%) retained detectable $\lg \mathrm{M}$ at baseline (i.e. the time of the first sampling). IgM titer did not appear to be boosted by the first vaccine dose, and titers decreased after the second dose. On the other hand, the first dose did appear to induce a significant increase $(p<0.0001)$ in the $\lg \mathrm{M}$ values in the unexposed subjects. Those values were boosted only in two subjects, but as expected, were not modified in any of the other 19 subjects (Supplementary Figure 5). Eight (8) out of the 21 unexposed patients (38.09\%) had no detectable lgM after the first dose. Only one patient failed to develop measurable $\lg \mathrm{M}$ antibodies after the two vaccine doses.

Finally, we looked at the contribution of the $\lg A$ isotype to the immune response after 412 pre-exposed $(p<0.0187)$ and unexposed groups $(p<0.0010)$ after the first vaccine dose. In 
medRxiv preprint doi: https://doi.org/10.1101/2021.06.02.21257975; this version posted August 10, 2021. The copyright holder for this preprint (which was not certified by peer review) is the author/funder, who has granted medRxiv a license to display the preprint in perpetuity. It is made available under a CC-BY-NC-ND 4.0 International license.

413 addition, the increase in $\lg \mathrm{A}$ titers was significantly higher in the pre-exposed $(p<0.0176)$ 414 vaccinated group compared to the unexposed, vaccinated group. The second boost resulted in 415 an additional significant increase in $\lg A$ titers in the unexposed, vaccinated population but not in 416 the pre-exposed vaccinated group (Supplementary Figure 5). 
medRxiv preprint doi: https://doi.org/10.1101/2021.06.02.21257975; this version posted August 10, 2021. The copyright holder for this preprint (which was not certified by peer review) is the author/funder, who has granted medRxiv a license to display the preprint in perpetuity.

It is made available under a CC-BY-NC-ND 4.0 International license .

\section{Discussion}

418 Our study followed a cohort of 59 subjects with prior exposure to SARS-CoV-2 with

419 the goal of describing the kinetics of the humoral immune response to natural infection over time.

420 This study uniquely examined a population of Hispanic/Latino persons disproportionately

421 impacted by the COVID-19 pandemic. We compared the kinetics of this antibody response in the

422 context of individuals with naturally acquired infection (pre-exposed) and unexposed individuals

423 following vaccination. None of the exposed subjects in our cohorts required hospitalization and

424 only had mild to moderate symptoms. Because of that, we found no differences in the serological

425 response according to symptoms severity. Consistent with other reports, we found that antibody

426 titers tended to wane over time and added to a growing body of evidence suggesting that

427 functional neutralization assays should serve as the gold standard for evaluating vaccine efficacy

428 in lieu of antibody binding quantification. Furthermore, we found that pre-exposed individuals

429 were able to mount an antibody response after just one vaccination dose that was equivalent to a

430 two-vaccine dose regiment in unexposed individuals. These findings have important implications

431 for defining the correlates of protection for SARS-CoV-2, as well as recommendations for future 432 public health guidelines and vaccine distribution efforts on a global scale.

433 One limitation of our work is the limited number of subjects sampled following natural

434 infection or vaccination. However, we were able to draw statistically significant conclusions from 435 our studies using 59 individuals. Additionally, our findings in this limited dataset are consistent 436 with previous reports, which have made great contributions to our understanding of the 437 immunological response to SARS-CoV-2 with a similar number of subjects (Bradley, Grundberg, 438 Selvarangan, LeMaster, Fraley, Banerjee, Belden, Louiselle, Nolte, Biswell, Pastinen, Myers and 439 Schuster 2021, Geers et al. 2021, Krammer, Srivastava, Alshammary, Amoako, Awawda, Beach, 440 Bermúdez-González, Bielak, Carreño, Chernet, Eaker, Ferreri, Floda, Gleason, Hamburger, 441 Jiang, Kleiner, Jurczyszak, Matthews, Mendez, Nabeel, Mulder, Raskin, Russo, Salimbangon, 442 Saksena, Shin, Singh, Sominsky, Stadlbauer, Wajnberg and Simon 2021, Prendecki, Clarke, 443 Brown, Cox, Gleeson, Guckian, Randell, Pria, Lightstone, Xu, Barclay, McAdoo, Kelleher and 444 Willicombe 2021).

445 We also acknowledge that setting up a longitudinal cohort study is always a 446 challenge. Particularly for COVID-19, it imposed additional difficulties due to the lockdowns, 447 social distancing measures, stigma associated with positive testing, and other significant 448 barriers. However, we assert that the limitations regarding the sampling sequence do not detract 449 from the significance of our findings. 
medRxiv preprint doi: https://doi.org/10.1101/2021.06.02.21257975; this version posted August 10, 2021. The copyright holder for this preprint (which was not certified by peer review) is the author/funder, who has granted medRxiv a license to display the preprint in perpetuity. It is made available under a CC-BY-NC-ND 4.0 International license .

Notably, our results contrast with reports describing a short persistence of neutralizing antibodies in plasma donors (Annen et al. 2021), but are in agreement with recent work 452 indicating that neutralizing antibodies may persist longer (Dan, Mateus, Kato, Hastie, Yu, Faliti, 453 Grifoni, Ramirez, Haupt, Frazier, Nakao, Rayaprolu, Rawlings, Peters, Krammer, Simon, 454 Saphire, Smith, Weiskopf, Sette and Crotty 2021, Klingler et al. 2020, Wajnberg, Amanat, Firpo, 455 Altman, Bailey, Mansour, McMahon, Meade, Mendu, Muellers, Stadlbauer, Stone, Strohmeier, 456 Aberg, Reich, Krammer and Cordon-Cardo 2020). Another work showed a long-term stabilization 457 of anti-Spike lgG value and nAbs lower than in early days post symptoms onset in a hospitalized 458 cohort (Dispinseri et al. 2021). The effect we are seeing in the samples with a decrease in the 459 total antibodies and titers in the second sample may be also a stabilization at a plateau. We have 460 followed up samples from 8 out of the 10 pre-exposed vaccinated subjects, but unfortunately, 461 alterations in the humoral response due to vaccination of these subjects limit our interpretation of 462 these results. Interestingly, the same group reported that nAbs are a correlate of survival and 463 that nAbs and, that anti-spike IgG persists in the vast majority of recovered patients regardless of 464 disease severity, age, and co-morbidities for up to eight months from symptoms onset 465 (Dispinseri, Secchi, Pirillo, Tolazzi, Borghi, Brigatti, De Angelis, Baratella, Bazzigaluppi, Venturi, 466 Sironi, Canitano, Marzinotto, Tresoldi, Ciceri, Piemonti, Negri, Cara, Lampasona and Scarlatti 467 2021). A longer follow up period would further our understanding of the antibody kinetics in a long-term period

We were able to show a similar trend in our cohort, with sustained neutralizing activity during the frame time of this study. The sustained neutralization capacity we observed remains highly relevant, despite the significant decline of IgG titers that we observed in this cohort. In 472 addition, we found that some subjects with undetectable $\lg G(n=6)$ and $\lg G$ titers $(n=11)$ retain 473 measurable neutralization activity, ranging from 32 to $76 \%$, as measured by a surrogate virus 474 neutralization assay. This finding is consistent with previous reports, suggesting that SARS-CoV4752 serological assays may be poorly-suited for prediction of serum neutralization potency, a metric 476 necessary to facilitate the establishment of the appropriate serologic correlates of protection 477 against SARS-CoV-2 (Muecksch et al. 2020). Our results suggest that functional assays 478 measuring neutralization potential should be implemented in studies of vaccine efficacy at the 479 population level.

$480 \quad$ From a technical point of view, the discrepancies between samples without detectable 481 antibodies but with neutralizing capabilities may be explained by differences in assays' 482 sensitivity. In our case, we use the same source of recombinant proteins for the antibodies and 483 surrogate neutralization assays. However, the serological assays include the full S1 and S2 
medRxiv preprint doi: https://doi.org/10.1101/2021.06.02.21257975; this version posted August 10, 2021. The copyright holder for this preprint (which was not certified by peer review) is the author/funder, who has granted medRxiv a license to display the preprint in perpetuity. It is made available under a CC-BY-NC-ND 4.0 International license .

484

485

486

487

488

489

490

491

492

493

494

495

496

497

498

499

500

501

502

503

504

505

506

507

508

509

510

511

512

513

514

515

516

517

regions of the Spike protein, which includes the $\mathrm{RBD}$, to coat the plate. The neutralization assay, however includes only the S1/RBD in suspension. It has been well documented that the binding of the protein to the plate results in altered antigen accessibility with a consequent presentation of different antigenic sites compared to native proteins (de Thier et al. 2015, Güven et al. 2014, Mannik et al. 1997, Taylor, Hurst, Charlton, Bailey, Kanji, McCarthy, Morrison, Huey, Annen, DomBourian and Knight 2021). Nevertheless, we showed a 93.7\% correlation between lgG titers and neutralization measured with a cPass SARS-CoV-2 Neutralizing Antibody Detection kit.

There are a limited number of publications on the contribution of different antibody isotypes to the immune response to this novel coronavirus. Early studies reported that spike- and RBD-specific $\lg M, \lg G 1$, and $\lg A$ antibodies were detected in most subjects early after infection, with all samples displaying neutralizing activity and $\lg M$ and $\lg G 1$ contributing most to neutralization (Klingler, Weiss, Itri, Liu, Oguntuyo, Stevens, Ikegame, Hung, Enyindah-Asonye, Amanat, Baine, Arinsburg, Bandres, Kojic, Stoever, Jurczyszak, Bermudez-Gonzalez, Nádas, Liu, Lee, Zolla-Pazner and Hioe 2020). A recent work reported that in a hospitalized cohort early presence of anti-RBD anti-spike IgA positively correlated with reduced persistence of SARSCoV-2 RNA in naso-pharyngeal swabs (Dispinseri, Secchi, Pirillo, Tolazzi, Borghi, Brigatti, De Angelis, Baratella, Bazzigaluppi, Venturi, Sironi, Canitano, Marzinotto, Tresoldi, Ciceri, Piemonti, Negri, Cara, Lampasona and Scarlatti 2021). Other work reported that early SARS-CoV-2specific humoral responses were dominated by $\lg A$ antibodies and that virus-specific antibody responses included $\lg \mathrm{G}$, $\lg \mathrm{M}$, and $\lg \mathrm{A}$. Furthermore, some studies have found that the $\lg \mathrm{A}$ isotype contributes to virus neutralization to a greater extent compared with IgG (Sterlin et al. 2021). In agreement with our results, recent work from India, a heavily impacted country by the pandemic found that RBD-specific $\lg$ but not $\lg \mathrm{A}$ or $\lg \mathrm{M}$ titers, correlated with neutralizing antibody titers and RBD-specific memory B cell frequencies (Nayak et al. 2021).In our work, we found that $\lg 1$ was the predominant isotype, while the $\lg A$ response was more limited. However, considering the non-significant changes in the $\lg A$ levels from the first to the second sample, a role for $\lg \mathrm{A}$ in sustained neutralization activity cannot be ruled out. On the other hand, in the majority of subjects in this cohort, IgM showed an expected trend to decline in the second collected sample. Two out of four subjects (ID265 and ID382) which were IgG-/lgM+, also had detectable neutralizing activity with detectable $\operatorname{lgM}$ both two and four months after the first samples were collected. These cases suggest that in some individuals, IgM may contribute to sustained neutralization capacity, as has been described before (Klingler, Weiss, Itri, Liu, Oguntuyo, Stevens, Ikegame, Hung, Enyindah-Asonye, Amanat, Baine, Arinsburg, Bandres, Kojic, Stoever, Jurczyszak, Bermudez-Gonzalez, Nádas, Liu, Lee, Zolla-Pazner and Hioe 2020). 
medRxiv preprint doi: https://doi.org/10.1101/2021.06.02.21257975; this version posted August 10, 2021. The copyright holder for this preprint (which was not certified by peer review) is the author/funder, who has granted medRxiv a license to display the preprint in perpetuity.

It is made available under a CC-BY-NC-ND 4.0 International license .

518 This result also corresponds with a Kappa analysis suggesting a fair Cohen's Kappa agreement 519 between IgM titers and neutralization capacity. Additional isotype-specific depletion experiments 520 are needed to determine the role of these antibodies in SARS-CoV-2 neutralization. Using 521 previous experience from our group (Serrano-Collazo et al. 2020, Steffen et al. 2020) those 522 experiments are underway using a larger number of well characterized individuals.

523 While the number of subjects in our vaccinated cohort (both unexposed and 524 previously exposed subjects) is limited, we show that vaccination induces a higher boost in the 525 magnitude of the humoral immune response, both at the level of S-specific $\operatorname{lgG}$ and 526 neutralization ability in the pre-exposed individuals compared to the naïve group. Our findings 527 also indicate that the second vaccine dose did not expand the S-specific antibodies, the total lgG 528 titers, or the neutralization capacity of blocking antibodies beyond the peak reached after the first 529 dose in the case of the pre-exposed cohort. One subject (ID112) received the Moderna 530 formulation (ID112) was identified as unexposed and without any known exposure to the SARS531 CoV-2, reach values in all three determinations comparable to that of the pre-exposed subjects. 532 Notably, however that volunteer worked in a high-risk environment during the first months of the 533 pandemic, and asymptomatic infection cannot be ruled out despite the absence of measurable 534 S-specific and neutralizing antibody titers at baseline.

$535 \quad$ Our study revealed two significant findings regarding vaccination. First is the rapid 536 decline of anti-S antibodies just 40 to 80 days (for unexposed or pre-exposed cohorts, 537 respectively) after a boost with the mRNA vaccine formulations. Second is the sustained level of 538 neutralization ability in the same period that anti-S antibodies are declining. This pattern is the 539 same as the one observed following naturally acquired SARS-CoV-2 infection in 59 subjects. In 540 addition, we observed that-while in both groups the decline of the total anti-S antibodies and 541 IgG titers was significant-the decline in titers was more precipitous in the unexposed group 542 relative to the pre-exposed group. Also highly significant is the observation that the baseline 543 neutralizing activity-but not the total antibody titers—was significantly higher among pre544 exposed individuals than the neutralization capacity induced by the first vaccine dose in the 545 unexposed group. This finding is reinforced by the fact that the time after natural infection and 546 the sample use as baseline before the vaccination was more than 4.7 months in average for all 54710 pre-exposed subjects. Our results also confirm that antibodies generated after the natural 548 infection, while similar in quantity, are significantly better in their function when natural infection 549 preceded vaccination. These results suggest that natural infection with SARS-CoV-2 may 550 contribute to the expansion of memory B cells, enabling the production of more S-specific 551 antibodies following vaccination. Together, these findings highlight the value of measuring both 
medRxiv preprint doi: https://doi.org/10.1101/2021.06.02.21257975; this version posted August 10, 2021. The copyright holder for this preprint (which was not certified by peer review) is the author/funder, who has granted medRxiv a license to display the preprint in perpetuity.

It is made available under a CC-BY-NC-ND 4.0 International license.

552 the function and quantity of S-specific antibodies to follow up humoral immune responses to the

553 vaccination. Our results agree with recent work wherein a predictive model of immune protection

554 from COVID-19 found that the level of neutralizing antibodies is highly predictive of immune

555 protection from symptomatic SARS-CoV-2 infection (Khoury, Cromer, Reynaldi, Schlub,

556 Wheatley, Juno, Subbarao, Kent, Triccas and Davenport 2021) and associated to recovery

557 (Dispinseri, Secchi, Pirillo, Tolazzi, Borghi, Brigatti, De Angelis, Baratella, Bazzigaluppi, Venturi,

558 Sironi, Canitano, Marzinotto, Tresoldi, Ciceri, Piemonti, Negri, Cara, Lampasona and Scarlatti 559 2021).

560 Our results on neutralization are built on using the RBD sequence from the original 561 SARS-CoV-2 virus. We do not know the variants infecting the subjects. However, all 59 subjects 562 in the serial sample's cohort were exposed to the SARS-CoV-2 from March to December 2020.

563 Only the 3 additional subjects in the pre-exposed and vaccinated cohorts were confirmed as 564 positive in the first two weeks of January 2021. During that period information about the 565 circulating variants in Puerto Rico was very limited. The first variant identified in Puerto Rico was 566 the Alpha variant (first identified in the UK, B.1.1.7) and was reported on January 28th, 2021. In 567 addition, from March 2020 to December 2020 the Government of Puerto Rico imposed a strict 568 lockdown limiting the travels to the island requiring mandatory testing upon arrival. By July 21 st, 5692021 , reports from the Surveillance System from the PR Department of Health and other private 570 institutions reported about 950 cases, with patients infected with at least nine (9) different 571 variants as follows: UK Alpha (B.1.1.7), New York (B.1.526), Brazil Gamma (P.1), California 572 Epsilon (B.1.429) and (B.1.427), California Eta (B.1.525), India Delta (B.1.617), Brazil Zeta (P.2), 573 Sudafrica Beta (B.1,351), India Kappa (B.1.617). We acknowledge that the neutralizing 574 properties of our samples may be modified when tested against the RBD from the variant of 575 interest and variant of concerns. However, a work testing four variants representing the original 576 SARS-CoV-2 strain and emerging variants with mutations in the spike protein suggested that 577 infection- and vaccine-induced immunity may be retained against the B.1.1.7 variant (Edara et al. 578 2021).

579 Of interest is the role of previous natural infection in driving antibody isotype 580 switching. Particularly in the case of $\lg \mathrm{A}$, our results showed that previous exposure led to a 581 faster increase in $\lg A$ titers after the first dose of vaccination, while unexposed subjects required 582 a second dose of vaccine to reach same levels of $\lg A$ titer of those pre-exposed to the novel 583 coronavirus.

Another critical aspect to be considered is the timing between the natural infection 585 and a potential vaccination against COVID-19. In accordance with the findings of other groups, 
medRxiv preprint doi: https://doi.org/10.1101/2021.06.02.21257975; this version posted August 10, 2021. The copyright holder for this preprint (which was not certified by peer review) is the author/funder, who has granted medRxiv a license to display the preprint in perpetuity. It is made available under a CC-BY-NC-ND 4.0 International license .

586 we highlighted the relevance of the time elapsed between infections or immunizations to induce 587 an optimal immune response (Miller et al. 2008, Pulendran and Ahmed 2006, Serrano-Collazo, 588 Pérez-Guzmán, Pantoja, Hassert, Rodríguez, Giavedoni, Hodara, Parodi, Cruz, Arana, Martínez, 589 White, Brien, de Silva, Pinto and Sariol 2020). Taking into account the results presented here 590 and those from previous works (Bradley, Grundberg, Selvarangan, LeMaster, Fraley, Banerjee, 591 Belden, Louiselle, Nolte, Biswell, Pastinen, Myers and Schuster 2021, Kumar et al. 2020, 592 Prendecki, Clarke, Brown, Cox, Gleeson, Guckian, Randell, Pria, Lightstone, Xu, Barclay, 593 McAdoo, Kelleher and Willicombe 2021), and considering the limited vaccine availability 594 worldwide, our findings suggest that immunity conferred by a single dose may be sufficient to 595 provide immune protection from severe disease in previously-exposed individuals. With this in 596 mind, second doses in previously exposed individuals may be deferred until the final phases of 597 vaccination campaigns and/or to be executed not before than 6 months after the documented 598 infection. Because of the limited number of samples, we were unable to identify any significant differences between the Pfizer-BioNTech or Moderna vaccine formulations.

We are aware of the limitations of this work owing to the limited number of participants and associated clinical data. We also understand that this work would benefit from an examination of the $\mathrm{T}$ cell compartment in unexposed and pre-exposed vaccinees, particularly in light of recent evidence that simple serological tests for SARS-CoV-2 antibodies do not reflect the richness and durability of immune memory to SARS-CoV-2 (Dan, Mateus, Kato, Hastie, Yu, Faliti, Grifoni, Ramirez, Haupt, Frazier, Nakao, Rayaprolu, Rawlings, Peters, Krammer, Simon, Saphire, Smith, Weiskopf, Sette and Crotty 2021). With this in mind, experiments characterizing the $\mathrm{T}$ cell response in our cohorts are underway.

608 Nevertheless, this work provides new and additional insight to the limited available data on 609 COVID-19 immune phenomena. Furthermore, this work also advances our understanding of 610 immune responses to the mRNA vaccine formulations in unexposed and pre-exposed 611 individuals, outside of the data provided by the vaccine manufactures. From our results, as well 612 as others (Bradley, Grundberg, Selvarangan, LeMaster, Fraley, Banerjee, Belden, Louiselle, 613 Nolte, Biswell, Pastinen, Myers and Schuster 2021, Khoury, Cromer, Reynaldi, Schlub, 614 Wheatley, Juno, Subbarao, Kent, Triccas and Davenport 2021, Krammer, Srivastava, 615 Alshammary, Amoako, Awawda, Beach, Bermúdez-González, Bielak, Carreño, Chernet, Eaker, 616 Ferreri, Floda, Gleason, Hamburger, Jiang, Kleiner, Jurczyszak, Matthews, Mendez, Nabeel, 617 Mulder, Raskin, Russo, Salimbangon, Saksena, Shin, Singh, Sominsky, Stadlbauer, Wajnberg 618 and Simon 2021, Prendecki, Clarke, Brown, Cox, Gleeson, Guckian, Randell, Pria, Lightstone, $619 \mathrm{Xu}$, Barclay, McAdoo, Kelleher and Willicombe 2021), the usefulness of a second vaccine dose 
620 in pre-exposed subjects remains inconclusive. Furthermore, the immune response elicited by

621 these vaccine formulations needs to be further evaluated to include the $\mathrm{T}$ cell compartment,

622 which serves as a critical component in the response to SARS-CoV-2 (Dan, Mateus, Kato,

623 Hastie, Yu, Faliti, Grifoni, Ramirez, Haupt, Frazier, Nakao, Rayaprolu, Rawlings, Peters,

624 Krammer, Simon, Saphire, Smith, Weiskopf, Sette and Crotty 2021, Grifoni et al. 2020,

625 Prendecki, Clarke, Brown, Cox, Gleeson, Guckian, Randell, Pria, Lightstone, Xu, Barclay,

626 McAdoo, Kelleher and Willicombe 2021, Weiskopf et al. 2020). Undoubtably, natural infection

627 confers a strong and high quality humoral and cellular immune response (Dan, Mateus, Kato,

628 Hastie, Yu, Faliti, Grifoni, Ramirez, Haupt, Frazier, Nakao, Rayaprolu, Rawlings, Peters,

629 Krammer, Simon, Saphire, Smith, Weiskopf, Sette and Crotty 2021, Goldberg et al. 2021,

630 Grifoni, Weiskopf, Ramirez, Mateus, Dan, Moderbacher, Rawlings, Sutherland, Premkumar,

631 Jadi, Marrama, de Silva, Frazier, Carlin, Greenbaum, Peters, Krammer, Smith, Crotty and Sette

632 2020). This fact has recently been underscored by work showing that variants of concern

633 partially escape humoral-but not T-cell-mediated-immune responses in COVID-19

634 convalescent donors and vaccinees (Geers, Shamier, Bogers, den Hartog, Gommers,

635 Nieuwkoop, Schmitz, Rijsbergen, van Osch, Dijkhuizen, Smits, Comvalius, van Mourik, Caniels,

636 van Gils, Sanders, Oude Munnink, Molenkamp, de Jager, Haagmans, de Swart, Koopmans, van

637 Binnendijk, de Vries and GeurtsvanKessel 2021). As the CDC's guidelines on the impact of the

638 vaccination on our lifestyles (travel quarantine and testing, maskless outside and indoors)

639 continues to change and evolve, it is remains unclear why immunity conferred by natural

640 infection is not taken in to account to support those guidelines, nor it is considered in the

641 progress towards attaining herd-immunity that may enable us to return to the new social

642 normality. In this context, our results are also highly relevant to consider standardizing methods

643 that both serve as a tool to follow up the immune response to the vaccination, but also to provide

644 a correlate of protection.

645

646 Conflict of Interest

647 The authors declare that the research was conducted in the absence of any commercial or

648 financial relationships that could be construed as a potential conflict of interest.

650 Authors Contribution

651 CAS and AME conceptualized the work and supervised the studies. PP supervised the work and 652 performed the serologic, neutralization test and supported the figures design. CSC, TRA, AA 653 execute the serological work. CC and GL selected samples from blood donors. JDB, AKP, CC, 
medRxiv preprint doi: https://doi.org/10.1101/2021.06.02.21257975; this version posted August 10, 2021. The copyright holder for this preprint (which was not certified by peer review) is the author/funder, who has granted medRxiv a license to display the preprint in perpetuity.

It is made available under a CC-BY-NC-ND 4.0 International license .

654 GL, PP contribute to the results discussion and analysis. DA, CPC, PP coordinate and supervise 655 the cohort's management and follow up. PP and TRA organized the data for future analysis. TA

656 provided administrative and regulatory support. JDB and AKP designed and supervised the

657 BSL3 work. ETS performed FRNT analysis. CAS wrote the initial draft, with the other authors

658 providing insights and concepts. ETS and AKP conducted the editorial work for the final

659 manuscript.

\section{Acknowledgements}

662 Authors want to thank the volunteers that were willing to participate and to contribute to science.

663 To llia Toledo, MT, Francheska Rivera, MT and Drs. Ivelisse Martin for their contribution and 664 diligent efforts to provide access to the samples from some presumptive-positive subjects 665 exposed to SARS-CoV-2. Particular acknowledgement is deserved for all administrative and 666 supportive staff at the Medical Sciences Campus, University of Puerto Rico, Laboratorio Clinico 667 Toledo, Laboratorio, Clinico Martin, Banco de Sangre Centro Médico and Banco de Sangre 668 Servicios Mutuos for their availability and commitment during the curfew imposed by the 669 quarantine period. Thanks also to the Latin clinical Trial Center' staff for their dedication 670 providing excellent care to the participants.

671 The Puerto Rico Science, Technology and Research Trust supported research reported in this 672 work under agreement number 2020-00272 to AME and CAS. Also, the University of Puerto Rico 673 contributed with the UPR-COVID-19 Grant to CAS and AME. This work was also supported by 674 1U01CA260541-01 to CAS (NCI/NIAID). This work was also partiallly funded by Saint Louis 675 University COVID-19 research Seed Funding to awarded to AKP and awarded to JDB. 
medRxiv preprint doi: https://doi.org/10.1101/2021.06.02.21257975; this version posted August 10, 2021. The copyright holder for this preprint (which was not certified by peer review) is the author/funder, who has granted medRxiv a license to display the preprint in perpetuity.

\section{References}

Annen K, Morrison TE, DomBourian MG, McCarthy MK, Huey L, Merkel PA, Andersen G, Schwartz E, Knight V. 2021. Presence and short-term persistence of SARS-CoV-2 neutralizing antibodies in COVID-19 convalescent plasma donors. Transfusion. Jan 16. Epub 2021/01/17. Baden LR, El Sahly HM, Essink B, Kotloff K, Frey S, Novak R, Diemert D, Spector SA, Rouphael N, Creech CB, et al. 2021. Efficacy and Safety of the mRNA-1273 SARS-CoV-2 Vaccine. N Engl J Med. Feb 4;384:403-416. Epub 2020/12/31. Bradley T, Grundberg E, Selvarangan R, LeMaster C, Fraley E, Banerjee D, Belden B, Louiselle D, Nolte N, Biswell R, et al. 2021. Antibody Responses after a Single Dose of SARS-CoV-2 mRNA Vaccine. New England Journal of Medicine. Dan JM, Mateus J, Kato Y, Hastie KM, Yu ED, Faliti CE, Grifoni A, Ramirez SI, Haupt S, Frazier A, et al. 2021. Immunological memory to SARS-CoV-2 assessed for up to 8 months after infection. Science.371:eabf4063. de Thier P, Bacharouche J, Duval JF, Skali-Lami S, Francius G. 2015. Atomic force microscopy analysis of IgG films at hydrophobic surfaces: a promising method to probe IgG orientations and optimize ELISA tests performance. Biochim Biophys Acta. Feb;1854:138-145. Epub 2014/12/17. Dispinseri S, Secchi M, Pirillo MF, Tolazzi M, Borghi M, Brigatti C, De Angelis ML, Baratella M, Bazzigaluppi E, Venturi G, et al. 2021. Neutralizing antibody responses to SARS-CoV-2 in symptomatic COVID-19 is persistent and critical for survival. Nat Commun. May 11;12:2670. Epub 2021/05/13.

Edara VV, Hudson WH, Xie X, Ahmed R, Suthar MS. 2021. Neutralizing Antibodies Against SARSCoV-2 Variants After Infection and Vaccination. Jama. May 11;325:1896-1898. Epub 2021/03/20. for the screening of SARS-CoV-2 antibodies. bioRxiv.2020.2006.2011.146332.

Figueiredo-Campos P, Blankenhaus B, Mota C, Gomes A, Serrano M, Ariotti S, Costa C, NunesCabaço H, Mendes AM, Gaspar P, et al. 2020. Seroprevalence of anti-SARS-CoV-2 antibodies in COVID-19 patients and healthy volunteers up to 6 months post disease onset. Eur J Immunol. Dec;50:2025-2040. Epub 2020/10/22.

Geers D, Shamier MC, Bogers S, den Hartog G, Gommers L, Nieuwkoop NN, Schmitz KS, Rijsbergen LC, van Osch JAT, Dijkhuizen E, et al. 2021. SARS-CoV-2 variants of concern partially escape humoral but not T-cell responses in COVID-19 convalescent donors and vaccinees. Science Immunology.6:eabj1750.

Goldberg Y, Mandel M, Woodbridge Y, Fluss R, Novikov I, Yaari R, Ziv A, Freedman L, Huppert A. 2021. Protection of previous SARS-CoV-2 infection is similar to that of BNT162b2 vaccine protection: A three-month nationwide experience from Israel. medRxiv.2021.2004.2020.21255670.

Grifoni A, Weiskopf D, Ramirez SI, Mateus J, Dan JM, Moderbacher CR, Rawlings SA, Sutherland A, Premkumar L, Jadi RS, et al. 2020. Targets of T Cell Responses to SARS-CoV-2 Coronavirus in Humans with COVID-19 Disease and Unexposed Individuals. Cell. May 20. Epub 2020/05/31. 
medRxiv preprint doi: https://doi.org/10.1101/2021.06.02.21257975; this version posted August 10, 2021. The copyright holder for this preprint (which was not certified by peer review) is the author/funder, who has granted medRxiv a license to display the preprint in perpetuity. It is made available under a CC-BY-NC-ND 4.0 International license .

720 Güven E, Duus K, Lydolph MC, Jørgensen CS, Laursen I, Houen G. 2014. Non-specific binding in 721 solid phase immunoassays for autoantibodies correlates with inflammation markers. J Immunol 722 Methods. Jan 31;403:26-36. Epub 2013/11/30.

723 Iyer AS, Jones FK, Nodoushani A, Kelly M, Becker M, Slater D, Mills R, Teng E, Kamruzzaman M, 724 Garcia-Beltran WF, et al. 2020. Persistence and decay of human antibody responses to the 725 receptor binding domain of SARS-CoV-2 spike protein in COVID-19 patients. Sci Immunol. Oct 726 8;5. Epub 2020/10/10.

727 Jeewandara C, Jayathilaka D, Gomes L, Wijewickrama A, Narangoda E, Idampitiya D, Guruge D,

728 Wijayamuni R, Manilgama S, Ogg GS, et al. 2021. SARS-CoV-2 neutralizing antibodies in patients 729 with varying severity of acute COVID-19 illness. Scientific reports. Jan 21;11:2062. Epub

730 2021/01/23.

731 Khoury DS, Cromer D, Reynaldi A, Schlub TE, Wheatley AK, Juno JA, Subbarao K, Kent SJ, Triccas JA, Davenport MP. 2021. Neutralizing antibody levels are highly predictive of immune protection from symptomatic SARS-CoV-2 infection. Nature Medicine. 2021/05/17. Klingler J, Weiss S, Itri V, Liu X, Oguntuyo KY, Stevens C, Ikegame S, Hung CT, Enyindah-Asonye G, Amanat F, et al. 2020. Role of IgM and IgA Antibodies in the Neutralization of SARS-CoV-2. J Infect Dis. Dec 24. Epub 2020/12/29.

737 Krammer F, Srivastava K, Alshammary H, Amoako AA, Awawda MH, Beach KF, BermúdezGonzález MC, Bielak DA, Carreño JM, Chernet RL, et al. 2021. Antibody Responses in Seropositive Persons after a Single Dose of SARS-CoV-2 mRNA Vaccine. N Engl J Med. Apr 8;384:1372-1374. Epub 2021/03/11.

741 Kumar S, Nyodu R, Maurya VK, Saxena SK. 2020. Morphology, Genome Organization,

742 Replication, and Pathogenesis of Severe Acute Respiratory Syndrome Coronavirus 2 (SARS-CoV2). In: Coronavirus Disease 2019 (COVID-19): Epidemiology, Pathogenesis, Diagnosis, and Therapeutics. Singapore: Springer Singapore. p. 23-31. L'Huillier AG, Meyer B, Andrey DO, Arm-Vernez I, Baggio S, Didierlaurent A, Eberhardt CS, Eckerle I, Grasset-Salomon C, Huttner A, et al. 2021. Antibody persistence in the first six months following SARS-CoV-2 infection among hospital workers: a prospective longitudinal study. Clin Microbiol Infect. Jan 19. Epub 2021/01/23.

Lau EHY, Tsang OTY, Hui DSC, Kwan MYW, Chan WH, Chiu SS, Ko RLW, Chan KH, Cheng SMS, Perera R, et al. 2021. Neutralizing antibody titres in SARS-CoV-2 infections. Nat Commun. Jan

752

753

754 4;12:63. Epub 2021/01/06.

Mannik M, Kapil S, Merrill CE. 1997. In patients with rheumatoid arthritis IgG binding to denatured collagen type II is in part mediated by IgG-fibronectin complexes. J Immunol. Feb 1;158:1446-1452. Epub 1997/02/01. Miller JD, van der Most RG, Akondy RS, Glidewell JT, Albott S, Masopust D, Murali-Krishna K, Mahar PL, Edupuganti S, Lalor S, et al. 2008. Human effector and memory CD8+ T cell responses to smallpox and yellow fever vaccines. Immunity. May;28:710-722. Epub 2008/05/13.

758 Muecksch F, Wise H, Batchelor B, Squires M, Semple E, Richardson C, McGuire J, Clearly S, 759 Furrie E, Greig N, et al. 2020. Longitudinal analysis of serology and neutralizing antibody levels 760 in COVID19 convalescents. J Infect Dis. Nov 3. Epub 2020/11/04.

761 Nayak K, Gottimukkala K, Kumar S, Reddy ES, Edara VV, Kauffman R, Floyd K, Mantus G, 762 Savargaonkar D, Goel PK, et al. 2021. Characterization of neutralizing versus binding antibodies 
medRxiv preprint doi: https://doi.org/10.1101/2021.06.02.21257975; this version posted August 10, 2021. The copyright holder for this preprint (which was not certified by peer review) is the author/funder, who has granted medRxiv a license to display the preprint in perpetuity.

It is made available under a CC-BY-NC-ND 4.0 International license .

and memory B cells in COVID-19 recovered individuals from India. Virology. Jun;558:13-21. Epub 2021/03/12.

Prendecki M, Clarke C, Brown J, Cox A, Gleeson S, Guckian M, Randell P, Pria AD, Lightstone L,

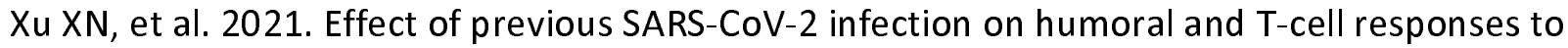
single-dose BNT162b2 vaccine. Lancet. Feb 25. Epub 2021/03/01.

Pulendran B, Ahmed R. 2006. Translating innate immunity into immunological memory: implications for vaccine development. Cell. Feb 24;124:849-863.

Sahin U, Muik A, Derhovanessian E, Vogler I, Kranz LM, Vormehr M, Baum A, Pascal K, Quandt J, Maurus D, et al. 2020. COVID-19 vaccine BNT162b1 elicits human antibody and $T(H) 1 T$ cell responses. Nature. Oct;586:594-599. Epub 2020/10/01.

Salazar E, Kuchipudi SV, Christensen PA, Eagar TN, Yi X, Zhao P, Jin Z, Long SW, Olsen RJ, Chen J, et al. 2020. Relationship between Anti-Spike Protein Antibody Titers and SARS-CoV-2 In Vitro Virus Neutralization in Convalescent Plasma. bioRxiv. Jun 9. Epub 2020/06/25.

Schmidt F, Weisblum Y, Muecksch F, Hoffmann H-H, Michailidis E, Lorenzi JCC, Mendoza P, Rutkowska M, Bednarski E, Gaebler C, et al. 2020. Measuring SARS-CoV-2 neutralizing antibody activity using pseudotyped and chimeric viruses. bioRxiv.2020.2006.2008.140871.

Serrano-Collazo C, Pérez-Guzmán EX, Pantoja P, Hassert MA, Rodríguez IV, Giavedoni L, Hodara V, Parodi L, Cruz L, Arana T, et al. 2020. Effective control of early Zika virus replication by Dengue immunity is associated to the length of time between the 2 infections but not mediated by antibodies. PLoS NegI Trop Dis. May;14:e0008285. Epub 2020/05/29.

Sette A, Crotty S. 2020. Pre-existing immunity to SARS-CoV-2: the knowns and unknowns. Nature Reviews Immunology. 2020/07/07.

Steffen TL, Stone ET, Hassert M, Geerling E, Grimberg BT, Espino AM, Pantoja P, Climent C, Hoft DF, George SL, et al. 2020. The receptor binding domain of SARS-CoV-2 spike is the key target of neutralizing antibody in human polyclonal sera. bioRxiv.2020.2008.2021.261727.

Sterlin D, Mathian A, Miyara M, Mohr A, Anna F, Claër L, Quentric P, Fadlallah J, Devilliers H, Ghillani $P$, et al. 2021. IgA dominates the early neutralizing antibody response to SARS-CoV-2. Sci Transl Med. Jan 20;13. Epub 2020/12/09.

Tan SS, Saw S, Chew KL, Huak CY, Khoo C, Pajarillaga A, Wang W, Tambyah P, Ong L, Jureen R, et al. 2020. Head-to-head evaluation on diagnostic accuracies of six SARS-CoV-2 serological assays. Pathology. Dec;52:770-777. Epub 2020/10/24.

Taylor SC, Hurst B, Charlton CL, Bailey A, Kanji JN, McCarthy MK, Morrison TE, Huey L, Annen K, DomBourian MG, et al. 2021. A New SARS CoV-2 Dual Purpose Serology Test: Highly Accurate Infection Tracing and Neutralizing Antibody Response Detection. Journal of Clinical Microbiology.JCM.02438-02420.

Voysey M, Clemens SAC, Madhi SA, Weckx LY, Folegatti PM, Aley PK, Angus B, Baillie VL, Barnabas SL, Bhorat QE, et al. 2021. Safety and efficacy of the ChAdOx1 nCoV-19 vaccine (AZD1222) against SARS-CoV-2: an interim analysis of four randomised controlled trials in Brazil, South Africa, and the UK. Lancet. Jan 9;397:99-111. Epub 2020/12/12.

Wajnberg A, Amanat F, Firpo A, Altman D, Bailey M, Mansour M, McMahon M, Meade P, Mendu DR, Muellers K, et al. 2020. SARS-CoV-2 infection induces robust, neutralizing antibody responses that are stable for at least three months. medRxiv.2020.2007.2014.20151126. 
medRxiv preprint doi: https://doi.org/10.1101/2021.06.02.21257975; this version posted August 10, 2021. The copyright holder for this preprint (which was not certified by peer review) is the author/funder, who has granted medRxiv a license to display the preprint in perpetuity. It is made available under a CC-BY-NC-ND 4.0 International license.

805 Walsh EE, Frenck RW, Jr., Falsey AR, Kitchin N, Absalon J, Gurtman A, Lockhart S, Neuzil K, 806 Mulligan MJ, Bailey R, et al. 2020. Safety and Immunogenicity of Two RNA-Based Covid-19 807 Vaccine Candidates. N Engl J Med. Oct 14. Epub 2020/10/15.

808 Weiskopf D, Schmitz KS, Raadsen MP, Grifoni A, Okba NMA, Endeman H, van den Akker JPC, 809 Molenkamp R, Koopmans MPG, van Gorp ECM, et al. 2020. Phenotype and kinetics of SARS810 CoV-2-specific T cells in COVID-19 patients with acute respiratory distress syndrome. Science 811 Immunology.5:eabd2071.

812

813 
medRxiv preprint doi: https://doi.org/10.1101/2021.06.02.21257975; this version posted August 10, 2021. The copyright holder for this preprint (which was not certified by peer review) is the author/funder, who has granted medRxiv a license to display the preprint in perpetuity.

A

Estimated Anti Spike-RBD SARS-CoV-2 IgG Titer

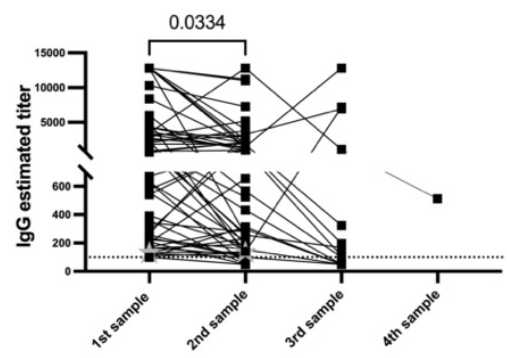

D

SVNT RBD/ACE2 on serial samples

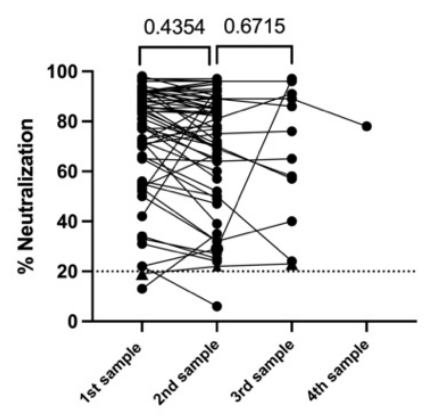

B

Decreased Anti Spike SARS-CoV-2 IgG Titers
C

Increased anti SARS-CoV-2 Spike IgG Titers

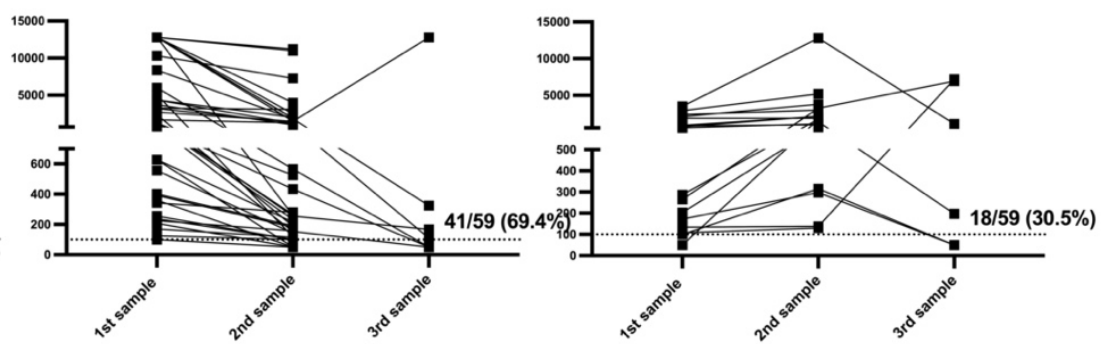

E

Neutralization decreased on serial samples

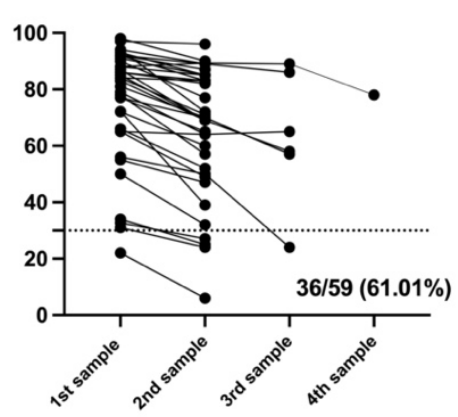

$\mathbf{F}$

Neutralization increased on serial samples

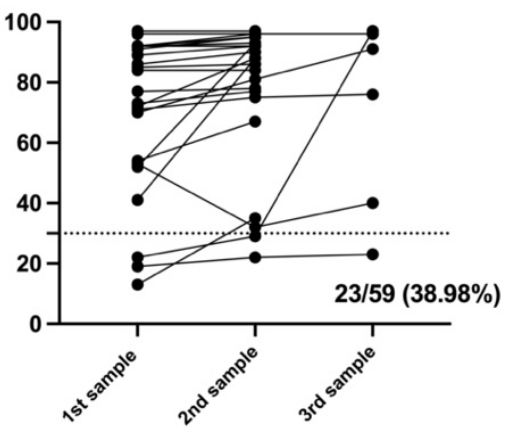

Figure 1

Figure 1: SARS-CoV-2 specific antibody titers decline over time, while neutralization ability is retained. The threshold for the total antibodies was 0.312 . The threshold for $\lg G$ titers was $1: 100$ and for the blocking activity was $30 \%$. Statistical significance was determined by 2way ANOVA multiple comparisons was used to test for increase or decrease among samples. $\mathrm{P}<0.05$ was considered significant. Samples 1 and 2 include the 59 subjects in the initial cohort before vaccination. Sample 3 encompass the 15 subjects from whom a collection of a third sample was completed. 
medRxiv preprint doi: https://doi.org/10.1101/2021.06.02.21257975; this version posted August 10, 2021. The copyright holder for this preprint (which was not certified by peer review) is the author/funder, who has granted medRxiv a license to display the preprint in perpetuity.

It is made available under a CC-BY-NC-ND 4.0 International license .

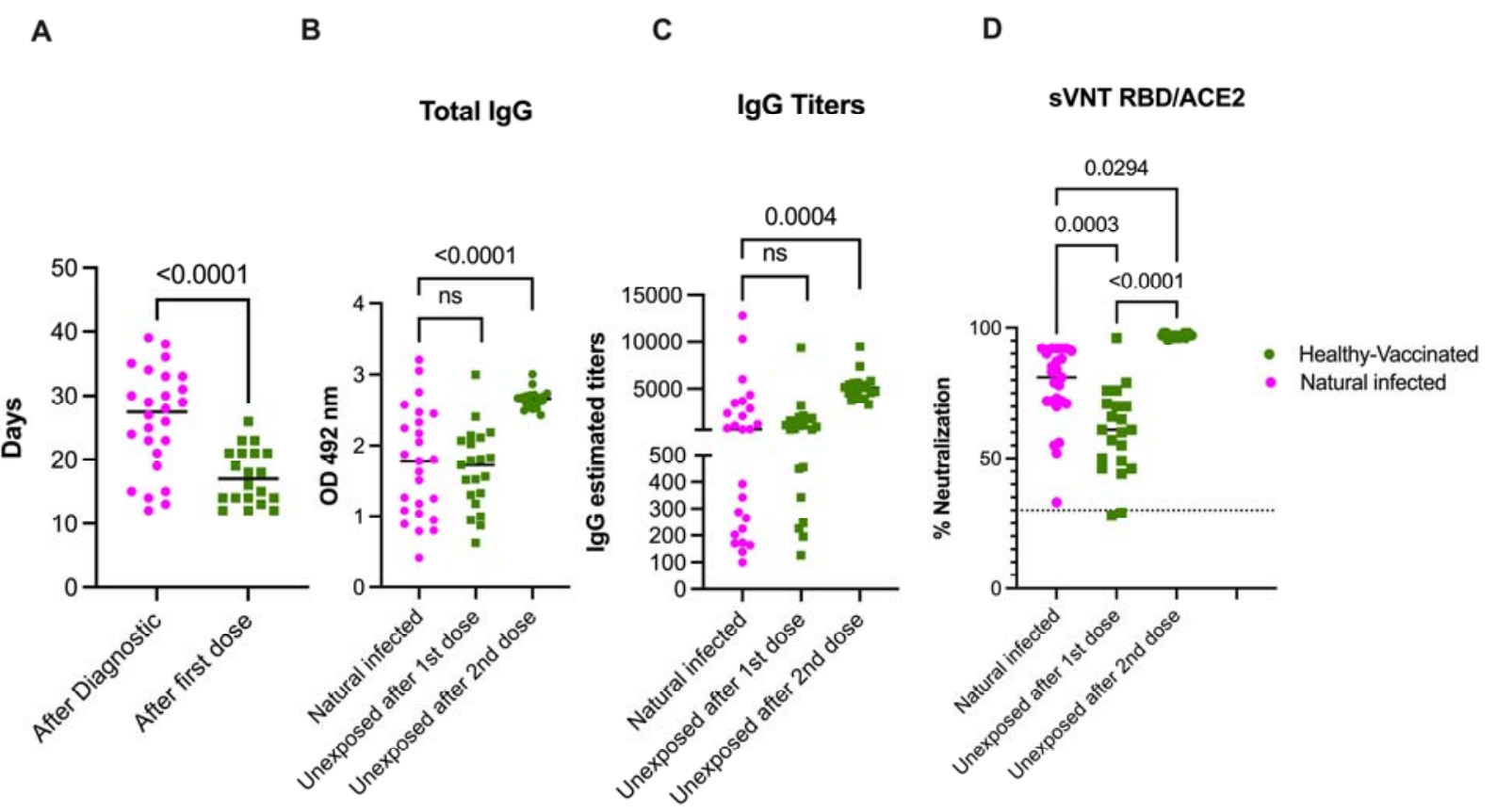

Figure 2

Figure 2: Naturally acquired SARS-CoV-2 infection primes an immune response superior to a single COVID-19 vaccine dose.

Panel A shows the mean time of sample collection following natural infection $(n=25)$ or after the first vaccine dose $(n=20)$. In panel $B$ and $C$, results from the total anti-Spike protein and the $\lg G$ titer measured by Enzyme-linked immunosorbent assay and expressed as OD or titers respectively are presented. The threshold for the total antibodies was 0.312 and the threshold for IgG titers was 1:100. All participants, except one, with previous exposure to SARS-CoV-2 showed detectable antibodies and measurable titers at baseline. Because the threshold 1:100 of our titration assay, the IgG titers at baseline in the unexposed subjects-which had no detectable S-specific antibodies-were set arbitrarily to 50 . Panel D shows the blocking activity of serum antibodies expressed as percentage of neutralization by using a surrogate viral neutralization test (sVNT). The cutoff for this assay was 30\%. As is shown, only one sample in the pre-exposed group contained antibodies below the threshold reported as more than $30 \%$ of neutralization. Also, while the distribution of antibodies and titers covers the full $Y$ axis, values in both panel B and C, and in panel D same samples are grouped on the top values area. Twoway ANOVA multiple comparisons or unpaired T test analysis was used to test for increases or decreases among samples. $\mathrm{P}<0.05$ was considered significant. Twenty-five participants (Natural infected) out of the 59 with the first sample collected between 12 and 39 days after the confirmed infection with SARS-CoV-2 were selected for comparison with the 21 unexposed851 
medRxiv preprint doi: https://doi.org/10.1101/2021.06.02.21257975; this version posted August 10, 2021. The copyright holder for this preprint (which was not certified by peer review) is the author/funder, who has granted medRxiv a license to display the preprint in perpetuity.

It is made available under a CC-BY-NC-ND 4.0 International license .

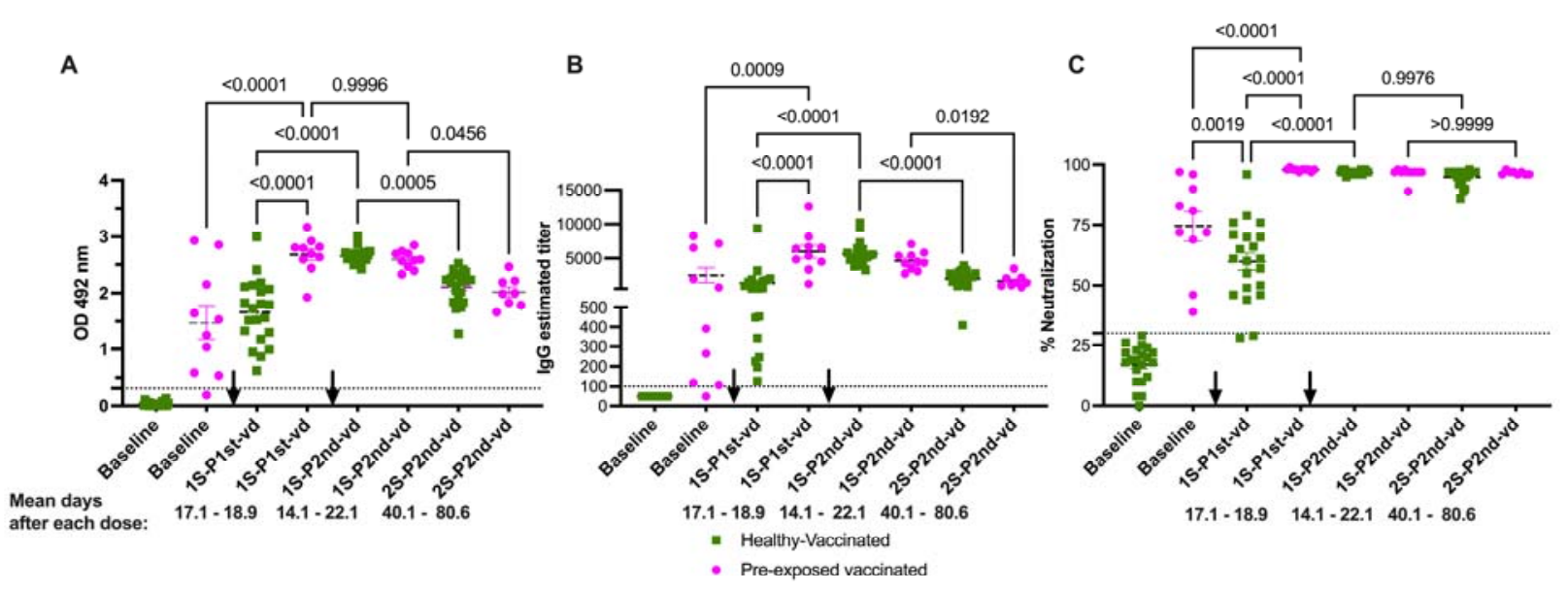

Figure 3: Functional neutralization assays are better predictors of the humoral immune response to COVID-19 mRNA-based vaccinations. Samples are described as 1st or 2nd samples after $1^{\text {st }}$ or $2^{\text {nd }}$ vaccine dose (1S-P1st-vd, 1S-P2nd-vd or 2S-P2nd-vd) and the mean time of samples collection is shown. Panels A and B show the total antibody and IgG titers, respectively, after full vaccination with two vaccine doses. Antibody levels and titers significantly decay in both groups in a second sample collected after the second vaccine (average of 60.3 and 100.5 days after the first vaccine dose for the unexposed and preexposed groups respectively). Despite the difference in sampling time between the two groups, there were no significant differences in the levels of antibodies or titers between groups in the 2S-P2nd-vd. Panel C shows antibody blocking capabilities measured by a surrogate viral neutralization assay (sVNT). Highly relevant is the finding that the blocking baseline activity of the pre-exposed individuals is significantly higher than the basely blocking activity induced by the first vaccine dose in unexposed individuals. In addition, two vaccine doses were necessary in the unexposed cohort to induce same percentage of neutralization achieved by just the first dose in the pre-exposed group. The magnitude of neutralization remained at similar levels until the last time point evaluated in both groups, confirming that the surrogate neutralization test is more suitable to determine the efficacy of the humoral immune response to the vaccine. The threshold for the total antibodies was 0.312. The threshold for IgG titers was 1:100 and for the blocking activity was $30 \%$. Statistical significance was determined by two-way ANOVA multiple comparisons to test for increase or decrease among samples. $p<0.05$ was considered significant. The black arrows indicate the moment of vaccine administration related to the timing of sample collection.

879 Healthy-vaccinated $(n=21)$ Pre-exposed vaccinated $(n=10)$. 
medRxiv preprint doi: https://doi.org/10.1101/2021.06.02.21257975; this version posted August 10, 2021. The copyright holder for this preprint (which was not certified by peer review) is the author/funder, who has granted medRxiv a license to display the preprint in perpetuity.

It is made available under a CC-BY-NC-ND 4.0 International license .

880 Supplementary Figure S1: Antibody subclasses isotypes in a longitudinal cohort of 59

881 volunteers exposed to SARS-CoV-2. Panel A shows the total anti-S antibodies in the second

882 set of samples collected an average of 67.8 days after the first set of samples (an average of

883108 days after PCR-confirmed SARS-CoV-2 infection). A third sample was collected from a

884 subset of the participants $(n=12)$ an average of 99.5 days after the second set of samples (an

885 average of 207 days after infection). Two different patterns in the kinetics of the antibody

886 response were identified: (1) $74.5 \%$ of samples showed a decrease in the binding from the time

887 of the first to the second sampling (Panel B) and (2) $25.4 \%$ of samples showed increased

888 values relative to the first sampling (Panel C). Panels D-G show the results of antibody binding

889 for the different subclasses tested, with IgG1 being the predominant subclass. Panels $\mathrm{H}$ and $\mathrm{I}$

890 show the results for IgM and $\lg A$ isotypes. Statistical significance was determined by two-way

891 ANOVA multiple comparisons to test for increase or decrease among samples. $\mathrm{p}<0.05$ was

892 considered significant. Sample 3 encompass the 15 subjects from whom a collection of a third

893 sample was completed. Panels D to I, includes the number of samples, from the initial cohort of

89459 subjects before vaccination, that were positive for each of the antibody's subtype or

895 subclasses as described in the results section. 
medRxiv preprint doi: https://doi.org/10.1101/2021.06.02.21257975; this version posted August 10, 2021. The copyright holder for this preprint (which was not certified by peer review) is the author/funder, who has granted medRxiv a license to display the preprint in perpetuity.

It is made available under a CC-BY-NC-ND 4.0 International license.

897 Supplementary Figure S2: Time elapsed between diagnosis and sample collection was 898 not significantly different between groups. There were no significant differences in the time 899 from diagnostic (Dx) to the first sample collection or between the first and the second samples 900 collection in both groups. Statistical significance was determined by two-way ANOVA multiple 901 comparisons was used. $\mathrm{p}<0.05$ was considered significant. Results are from the 59 subjects in 902 the initial cohort before vaccination. From two subjects in the increased titer and from one in the 903 decreased subgroups we were unable to establish the precise time of diagnostic.

904 
medRxiv preprint doi: https://doi.org/10.1101/2021.06.02.21257975; this version posted August 10, 2021. The copyright holder for this preprint (which was not certified by peer review) is the author/funder, who has granted medRxiv a license to display the preprint in perpetuity.

It is made available under a CC-BY-NC-ND 4.0 International license .

905 Supplementary Figure S3: IgG titers-but not IgM or IgA-correlate with neutralization. 906 Panel A shows the correlation between the neutralization capacity measured with the surrogate viral neutralization test (sVNT) and the total IgG titers, confirming a moderate agreement. Panel $B$ also shows moderate agreement between the sVNT and Focus Reduction Neutralization Tests (FRNT) using the whole virus. Panels $C$ and $D$ show a fair and a slight agreement between the neutralization activity and the $\lg M$ and $\lg A$ titers, respectively. All samples $(n=131)$ from the 59 subjects in the initial cohort, before vaccination, were included in the analysis for figures in panels $A, C$ and D. A subset of 15 samples with prior known FRNT results, were used for the correlation analysis showed in panel B. Cohen's Kappa agreement follow Landis and Koch scale. The values $(\mathrm{K})$ were considered as follows: poor agreement, $\mathrm{K}<0.02$ ); fair agreement, $\mathrm{K}=0.21$ to 0.4 ; moderate agreement, $\mathrm{K}=0.41$ to 0.6 ; substantial agreement, $\mathrm{K}=0.61$ to 0.8 ; very good agreement, $\mathrm{K}=0.81$ to 1.0 
medRxiv preprint doi: https://doi.org/10.1101/2021.06.02.21257975; this version posted August 10, 2021. The copyright holder for this preprint (which was not certified by peer review) is the author/funder, who has granted medRxiv a license to display the preprint in perpetuity. It is made available under a CC-BY-NC-ND 4.0 International license.

918 Supplementary Figure S4: Time elapsed between sample collection after vaccination. The 919 time between the first and second samples after the $1^{\text {st }}$ or the $2^{\text {nd }}$ vaccine dose (1S-P1st-vd, 1S920 P2st-vd) were similar in both groups (pre-exposed and unexposed vaccinated subgroups).

921 However, the time of collection of the third sample (2S-P2nd-vd) was significantly longer for the 922 pre-exposed group compared with the unexposed group. Statistical significance was determined by two-way ANOVA multiple comparisons were used. $p<0.05$ was considered significant. Unexposed and vaccinated group $n=21$. Pre-exposed and vaccinated group $n=10$. 
medRxiv preprint doi: https://doi.org/10.1101/2021.06.02.21257975; this version posted August 10, 2021. The copyright holder for this preprint (which was not certified by peer review) is the author/funder, who has granted medRxiv a license to display the preprint in perpetuity.

It is made available under a CC-BY-NC-ND 4.0 International license.

926 Supplementary Figure S5: $\lg$ G1, $\lg M$ and $\lg A$ are differentially boosted by the vaccination 927 in healthy or pre-exposed vaccinated subgroups. The boost of the lgG1 in both subgroups 928 agrees with the total antibodies' changes showed in figure 3 after each vaccine dose. First 929 vaccine dose induces a significant increase in the $\lg M$ values only in the unexposed healthy 930 subjects. The first vaccine dose significantly boosted the $\lg A$ values in both groups. The 931 increase in IgA titers was significantly higher in the pre-exposed vaccinated group compared to 932 the healthy-vaccinated group. The second vaccine boost resulted in an additional significant 933 increase in IgA titers only in the healthy-vaccinated group suggesting an advantage of the 934 second shot in naïve individuals. 